\title{
Project of Gasification plant for mechanized processing of household waste
}

\author{
Anastasiia Druzhinina ${ }^{1, *}$, Antonina Golubeva ${ }^{1}$, Eleonora Zhuravleva $^{2}$, Ekaterina Makarenko $^{3}$, and Anastasiia \\ Nedomovnaya $^{3}$ \\ ${ }^{1}$ CleanTech, Innovation Entrepreneurship, ITMO, Saint-Petersburg, Russia \\ ${ }^{2}$ Life Science, Innovation Entrepreneurship, ITMO, Saint-Petersburg, Russia \\ ${ }^{3}$ Innovation Economy, ITMO, Saint-Petersburg, Russia
}

\begin{abstract}
Humanity knows three ways to deal with waste: incineration, burial (landfills) and recycling. All the methods, except reuse and recycle, destroy nature and are dangerous for ecology and human health exactly. Each year Russians produce about 50 million tons solid waste, the most part of which goes to the landfills. National green projects are aimed to create visible eco-friendly system by awarding greenwashing projects with grants: landfills with sorting system, sorting centres without recycling facilities. Therefore, this study is aimed to discover recycling practices execute in Russia and suggest the project of gasification waste plant.
\end{abstract}

\section{Introduction}

Waste generation has increased massively around the world in recent decades, and there are no signs of it slowing down. This is due to a number of factors, such as population growth, urbanization, and economic growth, as well as consumer shopping habits. Only in 2018, the total waste generated in the EU-27 by all economic activities and households amounted to 2.317 million tonnes, and by 2050 generation of waste predicted to gain 3.4 billion tons [1].

Annually approximately 150 million tons of singleuse plastic are produced in the world, which is half of the total amount of generated waste. About 8 million tons fall into the world's oceans, causing harm of 40 billion US dollars. 127 countries have implemented facilities to minimize the damage associated with excessive consumption and waste generation. In Saudi Arabia, a ban was imposed on the production, advertising, sale, import, and use of disposable goods made of polypropylene and polyethylene, including personal hygiene products, bags, and utensils. Ireland has established a tax on plastic bags, and California has banned single-use bags with a density of fewer than 80 microns. Each country in the European Union, in accordance with the directive [2], establishes requirements for the reduction of waste generated.

The annual growth of landfills in Russia is 0.4 million hectares, which is comparable to the territory of Moscow and St. Petersburg. In 2018, the number reached 7.266 million tons of waste, which is $16.8 \%$ higher than in 2017 [3]. The specific indicator of the total volume of waste generation per unit of GDP in 2018 was 81.3 tons per 1 million rubbles or $400 \mathrm{~kg}$ per average Russian citizen. Over the past 8 years, the amount of municipal solid waste has increased by 4 million tons or $94.5 \%$, and most part of the waste goes to landfills.

\subsection{Methods of waste recycling}

There are several options for recycling waste into useful recyclables. Some of them cause severe environmental damage, while others, on the contrary, are more effective. There are three main technologies of recycling:

- landfill incineration - this method of waste disposal allows to free up a significant area of land, but it harms the environment. In the case the company is equipped with high-tech equipment that can filter all harmful components.

- plasma processing - can be applied for unsorted raw materials. As a result, secondary products are obtained, which can be used for the manufacture of building materials, ceramic tiles and other products.

- pyrolysis at low temperatures - one of the most effective and useful ways of recycling waste, as it has almost no negative impact on the environment and generates a large amount of heat that can be converted into electricity.

\subsection{Waste management in Russia}

The current waste management system in the Russian Federation is insufficient. Waste recycling covers about $5 \%$ of its total volume. This is a very small value since the volume of solid waste in the country increases by an average of $10 \%$ annually. Based on the «RosPrirodNadzor» statistics, the volume of municipal

\footnotetext{
* Corresponding author: anadar.smm@gmail.com
} 
solid waste is $55-60$ million tons per year and only $4-5 \%$ of MSW is sent for recycling or incineration [15]. The most of waste from the population, businesses, manufactures, etc. is disposed into landfills or in the World Ocean. The Ministry of Nature of the Russian Federation considers the best solution is to incinerate waste. For this purpose, according to the national project "Ecology", it is necessary to build 200 waste processing plants in Russia by 2024 [4]. The use of such plants allows for the processing of waste without pre-sorting.

An incineration plant is a technological object that recycles all carbon-containing waste, using incineration (thermal decomposition) in boilers and furnaces. A side function of incinerators is the generation of heat and electricity through the use of the heat of combustion [5].

\subsection{Existing problems of incineration plants in Russia}

If the incineration plant has a positive effect on the environment by cleaning it from waste, then the technologies used in the plants themselves are just as harmful to the environment. All furnaces in incinerators or waste processing plants produce huge amounts of slag, ash, and smoke. Those particles of furnace exhaust that are of considerable size, dispersed by the wind, create smog. It is equally dangerous both for human health and for the normal course of many processes in nature.

The gases, which in turn are released along with the ash, are much more dangerous. Many of them irritate the human respiratory tract, some are even poisonous, although there are quite a few of them. Sulphur oxides, flying out of the chimneys and entering the atmosphere, quickly turn into sulfuric acid, which then returns to earth in the form of acid rain.

Despite the fact of harm that can be provided by incinerating plants, to implement innovative solutions of recycling in Russia it is necessary to have a base of facilities which will be able to process the minimum amount of waste generated in the regions

Most of the existing incinerators in Russia do not satisfy European standards. Technological processes are outdated and require modernization. At a combustion temperature of $850^{\circ} \mathrm{C}$, a huge number of toxic compounds is released into the atmosphere. Defective filtration systems cannot reduce hazardous emissions to low concentrations. Heat treatment of unsorted waste proceeds with intensive emissions of highly toxic substances.

To safely escape the problem, the temperature in modern plants will reach $1260^{\circ} \mathrm{C}$, as a result of which the emissions of dioxin and heavy metals will be reduced to the permitted level. The slags remaining after the destruction of waste will be used for the production of building materials. The resulting energy will make up for the electrical energy.

List of currently working incineration plants in Moscow and the Moscow region:

- Plant №2 is the first in Russia, located on the Altufyevsky highway.
- Plant №3 is located in the south of Moscow (Podolsky Cadets Street).

- Plant №4 was built in Moscow on the territory of the industrial zone «Rudnevo».

- The Ecologist incineration plant in Lyubertsy.

\subsection{Incineration Plant №4}

For a more detailed study incineration Plant №4 was chosen to study the subject and its impact on the environment thoroughly. Multiple inspections were carried out on the impact of this plant on the environment and the nearest residential facilities. According to the information received, the number of registered oncological diseases in this area, which is located in the zone of influence of Plant №4 in the period from 2016 to 2019 , increased by 4.9 times. Also, among the residents of the Kosino-Ukhtomsky district, a stable increase in respiratory diseases was noted during this period.

Due to the lack of reliable information about the impact of emissions on the health of citizens and the state initiated an independent investigation of the condition of soils in the zone of influence Plant №4 in 2018. Activists from the group «STOP the Pollution!» was organized by the sampling and chemical analysis of soil samples around Moscow Plant №4. Three locations had been analysed:

- Moscow, Kosino-Ukhtomsky district, Mikrorayon Kozhukhovo, the distance is 1800 meters to Plant №4.

- Moscow, Nekrasovka district, Lyuberetskoe Pole microdistrict, 500 meters east of Plant №4.

- Moscow region, Balashikha, Saltykovsky forest Park on the border with Novokosino. The distance to Plant №4 is 3800 meters.

Chemical analysis of soils for dioxins, PCBs, and benz (a)pyrenees was carried out by the Laboratory of Analytical Ecotoxicology of the A. N. Severtsov Institute of Ecology and Evolution of the Russian Academy of Sciences. The results of the sample analyses are presented in Tables 1-3.

Table 1. Dioxins (PCDD / PCDF).

\begin{tabular}{|l|c|c|c|}
\hline Sampling point & $\begin{array}{c}\text { Value } \\
\text { TEQ } \\
\text { (ng/ } \\
\mathrm{kg})\end{array}$ & $\begin{array}{c}\text { AAC } \\
\text { (Approximate } \\
\text { allowable } \\
\text { concentrations) } \\
\text { Russia, } \\
\text { agricultural land } \\
\text { (ng / kg) }\end{array}$ & $\begin{array}{c}\text { AAC } \\
\text { Russia, } \\
\text { settlements } \\
\text { (ng/ kg) }\end{array}$ \\
\hline $\begin{array}{l}\text { Site 1 } \\
\text { (Kozhukhovo) }\end{array}$ & 5.1 & 5 & 50 \\
\hline $\begin{array}{l}\text { Site 2 } \\
\text { (Nekrasovka) }\end{array}$ & 24.9 & 5 & 50 \\
\hline $\begin{array}{l}\text { Site 3 } \\
\text { (Saltykovsky les) }\end{array}$ & 4.6 & 5 & 50 \\
\hline
\end{tabular}


Table 2. PCB (polychlorinated biphenyls).

\begin{tabular}{|l|c|}
\hline Sampling point & Value TEQ (ng / kg) \\
\hline $\begin{array}{l}\text { Site } 1 \\
\text { (Kozhukhovo) }\end{array}$ & 1.5 \\
\hline $\begin{array}{l}\text { Site } 2 \\
\text { (Nekrasovka) }\end{array}$ & 50.5 \\
\hline $\begin{array}{l}\text { Site } 3 \\
\text { (Saltykovsky les) }\end{array}$ & 2.8 \\
\hline
\end{tabular}

Table 3. Benzo(a)pyrene.

\begin{tabular}{|l|c|c|c|}
\hline \multicolumn{1}{|c|}{ Sampling point } & $\begin{array}{c}\text { Value, } \\
\mathrm{mg} / \mathrm{kg}\end{array}$ & $\begin{array}{c}\text { Value MPC } \\
\text { (maximum } \\
\text { permissible } \\
\text { concentration), } \\
\mathrm{mg} / \mathrm{kg}\end{array}$ & $\begin{array}{c}\text { Exceeding } \\
\text { the MPC, } \\
\text { times }\end{array}$ \\
\hline $\begin{array}{l}\text { Site 1 } \\
\text { (Kozhukhovo) }\end{array}$ & 0.068 & 0.02 & 3.4 \\
\hline $\begin{array}{l}\text { Site 2 } \\
\text { (Nekrasovka) }\end{array}$ & 0.379 & 0.02 & 19 \\
\hline $\begin{array}{l}\text { Site 3 } \\
\text { (Saltykovsky les) }\end{array}$ & 0.166 & 0.02 & 8.3 \\
\hline
\end{tabular}

The source of unorganized emissions of dioxins and dioxin-like compounds, as well as other toxicants, is the territory of incineration plant № 4. The temporary placement site of ash and slag waste is also there and dust particles containing pollutants are carried along with the air mass flows. It is worth noting that benz(a)pyrene is the most toxic representative of a large group of polyaromatic hydrocarbons (PAHs). Its content is an important indicator of the carcinogenic activity of soils and other natural environments. The content of benz (a)pyrene in all three soil samples is 68, 379 and 166 micrograms $/ \mathrm{kg}$. The standard of benz(a)pyrene for soils (MPC) is $0.02 \mathrm{mg} / \mathrm{kg}$. Consequently, in all samples of the soil cover benz(a)pyrene was detected.

\section{Materials and methods}

\subsection{Material}

Despite the depressing situation in Russia, there is experience in borrowing foreign technologies and their subsequent improvement.

It means that time to start to find ways to improve existing technologies. One of these technologies is gasification - combination of incineration and hightemperature pyrolysis with minimal concentration of oxygen or air and gasification agent in a gasifier reactor. As a result, in a recycling process produced a gas, called synthesis gas or syngas consisting mainly of $\mathrm{CO} 2$ and $\mathrm{H} 2$, which can be the material for producing such products as heat, power, cooling, gaseous, and liquid fuels as well as chemicals [11].

There are several installations using gasification as waste disposal, which are located in Germany, China, France, the Netherlands, the United Kingdom, and Finland [5]. Unfortunately, none of these plants are able to effectively eliminate $\mathrm{CO} 2$ emissions and also purify syngas for sale. Advanced plants based on plasma gasification of waste are rather expensive, have a long payback period, and a low service life.

Therefore, there is a need to create a cheap and efficient technology for waste disposal.

\subsection{Experimental plant}

We proposed an initiative to create an experimental waste gasification plant based on using a catalyst in the main gasification process. The first research showed that plant can be create on laboratory of ITMO university. One of ccomponent of waste gasification plant can be seen in the figure 1. The basis is taken from Frolov's cannon [4], which instead of an injector (numbered 4) has a detonation steam generator.

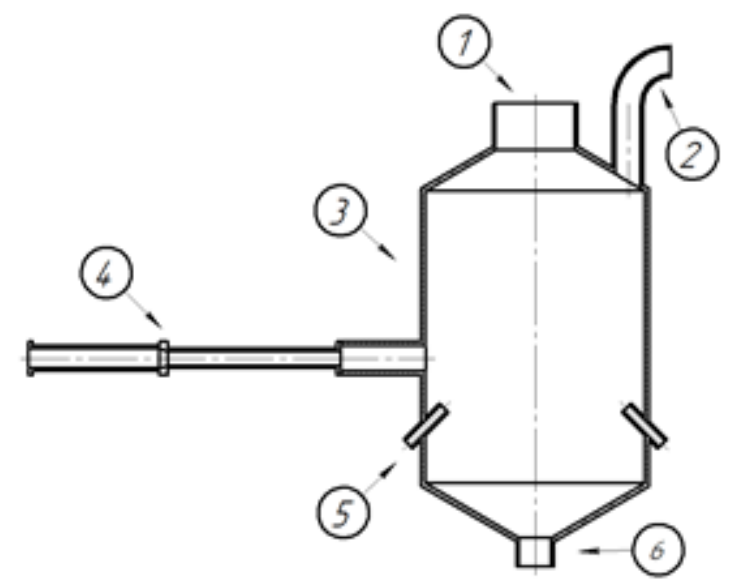

1 - loa ding node; 2 - syngas outlet; 3 - gasifier reactor; 4 -injector; 5 - gas bumers; 6 - slug outlet

Fig. 1. Component of waste gasification plant.

It is worth saying a few words about the technology planned for development.

Into a vacuum gasifier reactor (numbered 3), inside which gas burners (numbered 5) maintain a temperature of about $400^{\circ} \mathrm{C}$, waste is loaded through a loading node (numbered 1). After the ingress of waste in gasifier reactor, it is necessary to create a temperature equal to $950^{\circ} \mathrm{C}$ in the reactor to start gasification and the decomposition process. This can be done using a pneumatic feed of the catalyst through the injector (numbered 4), which will react with $\mathrm{CO}_{2}$ to form an exothermic process, that can be expressed by equation:

$$
\mathrm{CaO}+\mathrm{CO}_{2} \rightarrow \mathrm{CaCO}_{3}+177.8 \mathrm{kj} / \mathrm{mol}
$$

The using a catalyst has already proven the effectiveness [1], it means that very important to create experimental gasification plant to confirm the hypothesis and choose the most efficient catalyst for the catalysis process. In addition, there is a proposal are going to place the reactor-gasifier in a vacuum environment, so it is also necessary to check the efficiency of the catalyst in this.

Such low temperatures are due to the fact that the gasifier reactor will be in a vacuum with a reduced pressure, which will significantly reduce heat and energy costs. 


\subsection{Analytical methods}

In accordance with Supplement No. 8 to GN 2.1.6.133803, put into effect in 2010, Russia has established the corresponding "Maximum permissible concentrations (MPC) of pollutants in the ambient air of populated areas." The data is presented in the table 4.

Table 4. Maximum permissible concentration of air pollution.

\begin{tabular}{|c|c|c|}
\hline The code 3B & Appointment 3B & $\begin{array}{c}\text { MPC (maximum } \\
\text { one-time } \\
\text { concentration) }\end{array}$ \\
\hline 8 & $\begin{array}{c}\text { Suspended particles } \\
\text { PM 10 }\end{array}$ & 0.30 \\
\hline 10 & $\begin{array}{c}\text { Suspended particles } \\
\text { PM 2,5 }\end{array}$ & 0.16 \\
\hline
\end{tabular}

As a result of many studies, scientists have concluded that the content of PM 10 particles in urban air can reach $15-80 \%$. Moreover, most of the suspended particles enter the atmospheric air in those areas where industrial facilities are located. And ultrafine PMI particles (nanoparticles) can account for up to $40 \%$ of emissions of fine fractions (depending on the type of industrial facility). This is confirmed by the results of scientific studies by scientists from Germany, Cyprus and the United States, who came to the conclusion that by 2050 the global annual death rate from the effects of air pollution could reach 6.6 million people, which are twice as high as at present.

We assume to design a plant that is more environmentally friendly, capable of effectively reducing the amount of harmful substances entering the 1. A review of catalysts used in microwave assisted pyrolysis and gasification [Electronic resource] Available at: https://www.sciencedirect.com/science/article/pii/ S0960852419300471 (accessed: 22.02.2021)

2. V.V. Aleksashina, Ecology of the city, Waste incineration plants, Academia. Architecture and construction (2014)

3. Directive 2008/98/EC on waste (Waste Framework Directive) [Electronic resource] Available at: https://ec.europa.eu/environment/waste/framewor k/ (accessed: 20.02.2021)

4. Frolov's cannon, Safe and cheap method of waste disposal has no analogues in the world carriers [Electronic resource] Available at: http://www.ras.ru/news/shownews.aspx?id=c5b1 58a8-94d8-4d92-9c9f-a55724645fda (accessed: 18.02.2021)

5. Gasification of waste for energy carriers [Electronic resource] Available at: https://www.ieabioenergy.com/wpcontent/uploads/2019/01/IEA-Bioenergy-Task33-Gasification-of-waste-for-energy-carriers20181205-1.pdf (accessed: 20.02.2021)

6. G.R. Gibadullina, A.H. Tazmeev, R.N. Tazmeeva, The creation of high temperature steam flow for plasma chemical gasification of polymer waste, International Journal of Applied Engineering Research, 10 (24), 45015-45021 (2015)

7. Global municipal solid waste generation projection 2016-2050 [Electronic resource] Available at: https:/www.statista.com/statistics/916625/globalgeneration-of-municipal-solid-waste-forecast/ (accessed: 24.02.2021)

8. In Russia, by 2024,200 waste processing plants are to be built [Electronic resource] Available at: https://tass.ru/ekonomika/5935657 (accessed: 25.02.2021)

9. MPBO-2 plant in Yanino stops receiving waste [Electronic resource] Available at: https:/47news.ru/articles/186195/ (accessed: 20.02.2021)

10. F.D. Mubarakshina, A.A. Guseva, Modern problems and technologies of waste processing in Russia and abroad, Izvestiya Kazan State University of Architecture and Civil Engineering (2011)

11. Recent Trends in Gasification Based Waste-toEnergy [Electronic resource] Available at: https://www.intechopen.com/books/gasificationfor-low-grade-feedstock/recent-trends-ingasification-based-waste-to-energy (accessed: 21.02.2021)

12. State report "On the state and protection of the environment of the Russian Federation in 2017" (2017) [Electronic resource] Available at: https://www.mnr.gov.ru/docs/gosudarstvennye_d oklady/o_sostoyanii_i_ob_okhrane_okruzhayushc hey_sredy_rossiyskoy_federatsii/_ (accessed: 18.02.202 $\overline{1}$ )

13. A.K. Tazmeev, R.N. Tazmeeva, The material balance of process of plasma-chemical conversion of polymer wastes into synthesis gas, Journal of Physics: Conference Series, 789 (1), 012058 (2017)

14. Tutuk Joko Kusworo, Abdullah Busairi, Ahmad Fauzi Ismail, Azeman Mustafa, Budiyono, Purification of Biogas Using Carnon Nanotubes Mixed Matrix Membrane: Effect of Functionalization of Carbon Nanotubes Using Silane Agent, Sustainable Membrane Technology for Energy, Water, and Environment, 267-276 (2012)

15. Waste disposal in Russia, How the industry is being reformed [Electronic resource] Available at: https://tass.ru/info/6000776 (accessed: 20.02.2021). 